\title{
Peran Orang Tua, Pengaruh Teman Sebaya, Dan Sikap Berhubungan Dengan Perilaku Seksual Pranikah Pada Siswa-Siswi SMA Negeri 1 Jamblang Kabupaten Cirebon
}

\author{
Nina Nirmaya Mariani ${ }^{1}$, Siti Fatimah Murtadho ${ }^{2}$ \\ Program Studi Kebidanan Cirebon, Poltekes Kemenkes Tasikmalaya \\ e-mail: nina.nirmaya.mariani@gmail.com
}

\begin{abstract}
Adolescence is a transitional period from children to adulthood; thus, it is closely related to teenagers who do new things that want to be experienced such as expressing their feelings in the form of sexual behavior through dating. SKRRI findings in 2012 showed a fairly high rate in adolescents who had a lover had sexual behavior before marriage. Many factors that influence premarital sexual behavior include the role of parents, peer influence, and attitude. The objective of this research was to know the relation of parent role, peer influence, and attitudes to premarital sexual behavior at SMAN 1 Jamblang Cirebon regency in 2017. This was an observational study using a cross sectional design to find the relationship between parent role, peer influence, and attitude with premarital sexual behavior done quantitatively. The population was the students of SMAN 1 Jamblang the class of $X$ and XI $(n=268)$ as the study samples taken by purposive sampling. Data collection was done by distributing the questionnaire. The statistical analysis used univariate and bivariate. The findings showed that, based on chi-square test, there was a significant relation between parent role and pre-marital sexual behavior $(\varrho=0.004)$, peer influence and premarital sexual behavior $(\varrho=0.000)$, and attitude and pre-marital sexual behavior $(\varrho=0003)$.It is expected that there should be cross-sector collaboration in giving education about reproduction bealth especially about risk of premarital sexual behavior
\end{abstract}

Keywords: adolescent; attitude; parent role; peer influence; premarital sexual behavior

\begin{abstract}
ABSTRAK
Remaja merupakan masa transisi dari anak-anak menjadi dewasa, sehingga erat kaitannya dengan melakukan hal-hal baru yang ingin diketahuinya seperti mengekspresikan perasaannya dalam bentuk perilaku seksual melalui pacaran. Hasil temuan SKRRI tahun 2012 menunjukkan angka yang cukup tinggi pada remaja yang memiliki pacar pernah melakukan perilaku seksual pra nikah. Banyak faktor yang mempengaruhi perilaku seksual pra nikah diantaranya peran orang tua, pengaruh teman sebaya dan sikap. Tujuan penelitian adalah untuk mengetahui hubungan peran orang tua, pengaruh teman sebaya dan sikap terhadap perilaku seksual pra nikah di SMAN 1 Jamblang Kabupaten Cirebon tahun 2017.Penelitian ini merupakan jenis penelitian observasional menggunakan rancangan cross sectional untuk mencari hubungan antara peran orang tua, pengaruh teman sebaya, dan sikap dengan perilaku seksual pra nikah dengan pendekatan kuantitatif. Populasinya adalah siswa-siswi SMAN 1 Jamblang dengan sampel kelas X dan XI sebanyak 268 sampel diambil dengan cara purposive sampling. Pengumpulan data dilakukan dengan membagian kuesioner. Tahapan dalam analisis statistik yang digunakan adalah univariat dan bivariat.Adapun hasil penelitian berdasarkan uji chi square terdapat hubungan yang bermakna antara peran orang tua dengan perilaku seksual pra nikah $(\varrho=0,004)$, pengaruh teman sebaya dengan perilaku seksual pra nikah $(\varrho=0,000)$ dan sikap dengan perilaku seksual pra nikah $(\varrho=0,003)$.Diharapkan adanya
\end{abstract}


kerjasama dengan lintas sektoral dalam memberikan edukasi seputar kesehatan reproduksi khususnya tentang risiko perilaku seksual pra nikah

Kata Kunci : peran orang tua; perilaku seksual pra nikah; pengaruh teman sebaya; remaja; sikap

\section{PENDAHULUAN}

Remaja memiliki peran dalam menentukan tingkat pertumbuhan penduduk. Proporsi remaja di dunia menurut World Health Organization (WHO) diperkirakan 1,2 milyar atau sekitar seperlima dari jumlah penduduk dunia berumur 10-19 tahun. Proyeksi jumlah remaja di Indonesia sekitar seperlima jumlah penduduk yaitu 63,4 juta dari 237,6 juta penduduk Indonesia (Pratiwi, 2016). Kondisi yang sama terjadi di provinsi Jawa Barat pada tahun 2010 yaitu 7.354.900 penduduk remaja dari 43.053.732 jumlah penduduk. Sedangkan penduduk di Kabupaten Cirebon 2.223.089 diantaranya 566.251 penduduk merupakan remaja usia 10-22 tahun (Pusat Data dan Informasi Kemenkes RI, 2014).

Masa remaja merupakan periode terjadinya pertumbuhan dan perkembangan yang pesat baik secara fisik, psikologis maupun intelektual. Menurut Clarke-Stewart \& Friedman, (1987); Ingersoll, (1989) pada periode ini pula remaja mulai melepaskan diri secara emosional dari orang tua untuk menjalankan peran sosial barunya sebagai orang dewasa, sehingga erat kaitannya remaja melakukan hal-hal baru yang ingin diketahuinya menjadi orang dewasa seperti mengekspresikan perasaannya melalui pacaran dalam bentuk perilaku seksual (Agustiani, 2009). Perilaku seksual remaja dapat berupa tingkah laku yang dimulai dari perasaan tertarik, berkencan, berpegangan tangan, mencium pipi, berpelukan, mencium bibir, memegang buah dada di atas baju atau dibalik baju, memegang alat kelamin di atas atau di balik baju, dan melakukan senggama (Sarwono, 2007).

Hal tersebut sesuai dengan hasil Survei Kesehatan Reproduksi Remaja Indonesia (SKRRI) tahun 2012 sebanyak 79,6\% remaja pria dan $71,6 \%$ remaja wanita pernah berpegangan tangan dengan pasangannya. Untuk "level pacaran" yang lebih tinggi, survei menemukan sebanyak 48,1\% remaja laki-laki dan 29,3\% remaja wanita pernah berciuman bibir. Di level yang lebih tinggi, ditemukan sebanyak 29,5\% remaja pria dan $6,2 \%$ remaja wanita pernah meraba atau merangsang pasangannya. Fenomena ini dapat berlanjut ke level yang lebih tinggi lagi seperti melakukan hubungan seks pra nikah (Agung, 2016). Sejalan dengan hasil Survei Demografi Kesehatan Indonesia 
(SDKI) tahun 2012 yang menyatakan bahwa remaja pria usia 15-19 tahun yang pernah melakukan seks pra nikah sebanyak 4,5\%, sedangkan pada remaja wanita usia 15-19 tahun sebanyak 0,7\%. Angka ini cenderung meningkat pada remaja pria dibanding hasil temuan SDKI 2007 yaitu 3,7\% (Pusat Data dan Informasi Kemenkes RI, 2012).

Menurut Suparmi and Isfandari (2016) remaja bukan hanya rentan melakukan perilaku seksual tetapi juga rentan terhadap perilaku berisiko seperti merokok, konsumsi alkohol, penyalahgunaan narkoba, Kehamilan Tidak Diinginkan (KTD), pernikahan dini, aborsi tidak aman, ancaman terhadap Penyakit Menular Seksual (PMS) dan Human Immuno Deficiency Virus Acquired Immuno Deficiency Syndrome (HIV/AIDS). Secara global kasus HIV/AIDS terjadi pada kaum muda 15-24 tahun. HIV/AIDS diperkirakan setiap hari ada 7000 remaja terinfeksi HIV/AIDS. Menurut Direktorat Jenderal Pengendalian Penyakit dan Penyehatan Lingkungan Republik Indonesia (Ditjen PP \& PL RI) tahun 2012 jumlah kasus HIV dan AIDS di Indonesia yang dilaporkan hingga Juni 2012 mencapai 86.762 untuk kasus HIV dan AIDS mencapai 32.103 dengan jumlah kematian 5.623 jiwa, jumlah penderita usia 15-19 tahun sebanyak 1.134 jiwa dan jumlah penderita dengan faktor risiko heteroseksual sebanyak 18.680 jiwa (Nuzulia Rahayu et al., 2013).

Perilaku berisiko pada remaja bukan hanya mengenai kasus HIV/AIDS, di Indonesia angka aborsi diperkirakan mencapai 2,3 juta kasus per tahun. Sebanyak 230 ribu sampai 575 ribu remaja putri belum menikah melakukan aborsi setiap tahunnya. Kasus ini meningkat antara 150 ribu hingga 200 ribu kasus setiap tahun. Bahkan Data Kesehatan Nasional tahun 2012 menyatakan dari 400 ribu kasus aborsi di Jawa Barat separuhnya dilakukan oleh remaja (Pratiwi, 2016). Dengan demikian kelompok yang memiliki risiko tinggi secara seksual maupun kesehatan reproduksi, karena rasa keingintahuannya yang besar dan ingin mencoba sesuatu yang baru tanpa diimbangi dengan pertimbangan yang matang (Syamsulhuda B. Musthofa and Winarti, 2010).

Kedewasaan remaja dalam bergaul masih dalam tahap rasa ingin tahu dan ingin mencoba. Istilah pacaran mereka kenal sejak awal masa remaja. Tidak menutup kemungkinan remaja yang memiliki pacar aktif dalam berperilaku seksual (Sulistianingsih, 2010). Penelitian Nursal (2008) di SMA Kota Padang menunjukkan 
16,6\% remaja berperilaku seksual berisiko, diantaranya 4,3\% telah melakukan hubungan seksual dengan pacar (100\%). Alasan terbanyak yang dikemukakan adalah ungkapan kasih sayang sebanyak $80 \%$, tempat tersering dilakukan di tempat rekreasi $(53,3 \%)$ dan di rumah (46,7\%). Sedangkan Fakultas Psikologi Universitas Padjadjaran menunjukkan bahwa remaja yang pernah melakukan hubungan seks pra nikah di Bandung sebanyak 21,75\%, Cirebon 31,60\%, Bogor 30,85\% dan Sukabumi 26,4\% (Fridya Mayasari and Hadjam, 2000). Pangkahila tahun 1997 mengatakan terjadinya perubahan pandangan perilaku seksual dipengaruhi oleh banyak faktor remaja diantaranya pola pergaulan bebas, pengawasan dan perhatian orang tua dan keluarga yang longgar, lingkungan permisif, banyak hal yang sering dijumpai memberikan rangsangan seksual dan fasilitas pandangan seperti pacaran yang mempengaruhi perilaku seksual (Nursal, 2008). Hal tersebut sesuai dengan penelitian yang dilakukan oleh Sri Putri Murtini Puspita et al. (2012) yaitu hubungan antara pengetahuan, sikap, dan peran orang tua terhadap perilaku seks remaja.

Sikap dan peran orang tua memberikan kontribusi besar terhadap perilaku seks remaja selain dari pengetahuan. Sikap adalah respon tertutup yang tidak dapat dilihat langsung, sehingga remaja yang mempunyai sikap positif terhadap perilaku seks maka berpotensi untuk berperilaku positif cukup besar pula. Sama halnya remaja yang melakukan komunikasi tidak aktif dengan orang tuanya memiliki kecenderungan berperilaku seks risiko berat dibanding dengan remaja yang melakukan komunikasi aktif dengan orang tuanya (Sri Putri Murtini Puspita et al., 2012).

Selain hal di atas Joko Sapto Pramono et al. (2010) mengatakan terdapat pengaruh yang bermakna antara teman sebaya terhadap perilaku seksual remaja. Teman sebaya merupakan sarana yang lebih mudah dan terbuka dalam perilaku, tapi informasi tersebut lebih banyak mengandung pengalaman seksual yang dapat membawa remaja berperilaku seksual kurang sehat sehingga besar kemungkinannya remaja terpengaruh oleh teman sebayanya yang banyak bercerita mengenai pengalaman seksualnya. Yusuf (2005) mengemukakan ternyata teman sebaya berkaitan dengan baik tidaknya hubungan keluarga. Hubungan yang baik dengan orang tua cenderung dapat mencegah dari pengaruh negative teman sebayanya. 


\section{METODE PENELITIAN}

Metode penelitian adalah analitik dengan pendekatan cross sectional yang bertujuan untuk mencari hubungan antara peran orang tua, pengaruh teman sebaya, dan sikap dengan perilaku seksual pra nikah. Populasi dalam penelitian ini adalah seluruh seluruh siswasiswi SMA Negeri 1 Jamblang kelas X, XI, dan XII yang berjumlah 1.135 siswa. Teknik yang digunakan dalam pengambilan sampel menggunakan purposive sampling, yaitu kelas X dan XI berjumlah 812 siswa..Adapun besaran sampel sampelnya yaitu sebanyak 268 siswa, dengan cara pengambilan sampel menggunakan proportional random sampling. Adapun kriteria inklusi dan eksklusi untuk pengambilan sampel. Kriteria inklusi yaitu responden siswa-siswi kelas $\mathrm{X}$ dan $\mathrm{XI}$, bersedia menjadi responden, tinggal satu rumah dengan orang tua/ wali, sedangkan kriteria eksklusinya yaitu siswa-siswi yang tidak hadir dengan alasan sakit/ izin/ tanpa keterangan.Pengumpulan data menggunakan kuesioner yang telah dilakukan uji validitas dan realibilitas sebelumnya. Kuesioner tentang peran orang tua, pengaruh teman sebaya, sikap dan perilaku seksual pranikah menggunakan pertanyaan tertutup. Penilaian pada setiap variabel dibagi menjadi 2 kategori dengan menggunakan acuan nilai skor ratarata (mean). Analisis data yang digunakan dalam penelitian iini adalah analisis univariat dan bivariat. Adapun analisis univariat dibuat dalam bentuk tabel frekuensi (prosentase), sedangkan analisis bivariat menggunakan uji statistik chi square dengan menggunakan program SPSS dan tingkat kepercayaan $\alpha=0,05$.

\section{HASIL}

Hasil penelitian pada analisis univariat yang dilaksanakan di SMA Negeri 1 Jamblang Kabupaten Cirebon Tahun 2017 pada Tabel 1.

Berdasarkan Tabel 1 menunjukkan bahwa siswa siswi di SMA Negeri 1 Jamblang mayoritas memiliki peran orang tua yang baik yaitu $52,2 \%$, memiliki pengaruh yang tinggi dari teman sebaya sebanyak $54,5 \%$, memiliki sikap yang positif terhadap kesehatan reproduksi sebanyak 63,4\% dan mayoritas memiliki perilaku seksual pranikah berisiko rendah yaitu sebanyak $54,1 \%$.

Berdasarkan Tabel 2 di dapatkan bahwa peran orang tua, pengaruh teman sebaya dan sikap memiliki nilai $\rho$ value $<0,05$ dengan tingkat kemaknaan $\propto=0,05$. Maka dapat disimpulkan bahwa Ha diterima artinya ada hubungan antara peran orang tua, pengaruh teman sebaya dan sikap dengan perilaku seksual pra nikah di SMA negeri 1 Jamblang Kabupaten Cirebon. 
Tabel 1 Distribusi Frekuensi Peran Orang tua, Pengaruh teman sebaya, Sikap dan Perilaku Seksual Pra Nikah di SMAN 1 Jamblang Kabupaten Cirebon

\begin{tabular}{lcc}
\hline \multirow{2}{*}{ Variabel } & \multicolumn{2}{c}{ Total } \\
\cline { 2 - 3 } & Jumlah & $\%$ \\
\hline Peran orang tua & 140 & 52,2 \\
Baik & 128 & 47,8 \\
Tidak & 146 & 54,5 \\
\hline Pengaruh teman sebaya & 122 & 45,5 \\
Ya & & \\
Tidak & 170 & 63,4 \\
\hline Sikap & 96 & 36,6 \\
Positif & & \\
Negatif & 145 & 54,1 \\
\hline Perilaku Seksual Pranikah & 123 & 45,9 \\
Berisiko Rendah & & \\
berisiko Tinggi & & \\
\hline
\end{tabular}

Tabel 2 Hubungan Peran Orang tua, Pengaruh Teman Sebaya Dan Sikap Terhadap Perilaku Seksual Pra Nikah di SMAN 1 Jamblang Kabupaten Cirebon

\begin{tabular}{|c|c|c|c|c|c|c|c|}
\hline \multirow{3}{*}{ Variabel } & \multicolumn{4}{|c|}{ Perilaku Seksual Pranikah } & \multirow{2}{*}{\multicolumn{2}{|c|}{ Total }} & \multirow{3}{*}{$P$ value } \\
\hline & \multicolumn{2}{|c|}{ Berisiko Ringan } & \multicolumn{2}{|c|}{ BerisikoBerat } & & & \\
\hline & $\mathrm{N}$ & $\%$ & $\mathrm{~N}$ & $\%$ & $\mathrm{~N}$ & $\%$ & \\
\hline \multicolumn{8}{|l|}{ Peran orang tua } \\
\hline Baik & 88 & 62,9 & 52 & 37,1 & 140 & 100 & \multirow[t]{2}{*}{0,004} \\
\hline Tidak & 57 & 44,5 & 71 & 55,5 & 128 & 100 & \\
\hline \multicolumn{8}{|c|}{ Pengaruh teman sebaya } \\
\hline Ya & 58 & 39,7 & 88 & 60,3 & 146 & 100 & \multirow{2}{*}{0,000} \\
\hline Tidak & 87 & 71,3 & 35 & 28,7 & 122 & 100 & \\
\hline \multicolumn{8}{|l|}{ Sikap } \\
\hline Positif & 104 & 61,2 & 66 & 38,8 & 170 & 100 & \multirow[t]{2}{*}{0,003} \\
\hline Negatif & 41 & 41,8 & 57 & 58,2 & 98 & 100 & \\
\hline
\end{tabular}

\section{PEMBAHASAN}

Berdasarkan hasil penelitian terdapat hubungan antara peran orang tua dengan perilaku seksual pra nikah. Hasil penelitian sejalan dengan penelitian Darmasih (2009) yang mengatakan semakin tinggi peran keluarga pada remaja, maka perilaku seks pra nikah semakin baik, dan sebaliknya. Meningkatnya peran keluarga maka terjadi penurunan perilaku seksual pra nikah, dan sebaliknya.

Keluarga merupakan unit sosial terkecil yang bersifat universal yang dibagi ke dalam dua pola keluarga yakni keluarga inti dan keluarga luas. Keluarga inti terdiri atas suami atau ayah, istri atau ibu, dan anak-anak yang lahir dari perkawinan antara keduanya dan yang belum berkeluarga (termasuk anak tiri). 
Sedangkan keluarga luas terdiri dari suami, istri, anak yang belum menikah, mertua, adik atau kakak ipar, pembantu rumah tangga atau orang yang tinggal menumpang. Akan tetapi dalam masanya keluarga mengalami banyak perubahan di masyarakat yakni orang tua yang bercerai, salah satu atau kedua orang tua yang meninggal, keluarga tiri, orang tua yang bekerja, dan adopsi yang dapat mempengaruhi perkembangan remaja terutama dalam hal berperilaku semakin buruk jika keluarga mengalami disfungsi sebagaimana yang disebutkan (Yusuf, 2005).

Penelitian lain dengan hasil yang sama yaitu penelitian Nirmajanti (2015) yang menyatakan bahwa sebagian besar responden memiliki perilaku seksual pra nikah baik dengan peran orang tua baik. Konsep diri anak dipengaruhi oleh peran orang tua. Orang tua dan orang dewasa lain (wali) memberikan peluang untuk terjadinya interaksi antara anak dengan masyarakat. Dengan demikian orang tua berusaha agar anak mampu melakukan penyesuaian diri terhadap lingkungan sosialnya dengan cara menerapkan aturan pada anak melalui kebiasaan yang dilakukan sehari-hari, sehingga dapat meminimalisir kejadian perilaku seksual dini maupun berisiko tinggi (Agustiani, 2009).
Hasil penelitian Nursal (2008) menunjukkan hasil yang sama yaitu pola asuh orang tua dengan perilaku seksual pra nikah memiliki hubungan yang bermakna. Responden dengan pola asuh permisif mempunyai peluang 6,0092 kali berperilaku seksual berisiko berat dibandingkan demokratis \& otoriter $\quad(95 \% \mathrm{CI}=131,9-2736,8)$. Nursal mengatakan salah satu faktor risiko perilaku seksual risiko tinggi adalah pola asuh orang tua diantaranya dalam hal pengawasan orang tua terhadap anak.

Pengawasan orang tua terhadap remaja dan memiliki interaksi yang aktif dengan orang tuanya cenderung dapat menunda bahkan menghindari perilaku hubungan seksual pada remaja. Sedangkan pada remaja yang tidak mendapatkan pengawasan orang tua dapat mempercepat melakukan hubungan seksual pertama pada usia lebih dini. Orang tua remaja yang memiliki perilaku yang tidak sehat, seperti merokok, orang tua tersebut cenderung memiliki perilaku seksual yang sangat aktif dan berisiko tinggi sejak usia sangat muda.Peran orang tua sebagai pengontrol perilaku anak dibutuhkan ketika remaja sedang menghadapi masa transisi dari anak-anak ke dewasa, karena pada masa ini remaja sedang dalam kondisi perasaan dan kejiwaannya yang mudah berubah. Orang tua pada 
hakikatnya merupakan faktor utama yang mempengaruhi perkembangan moral anak. Tanpa adanya pengawasan dari orang tua, anak dapat terjerumus dalam hal-hal negatif. Perilaku orang tua juga mempengaruhi perkembangan moral anak jika perilaku orang tua baik kemungkinan perilaku anaknya juga baik, dan sebaliknya. Maka dari itu orang tua berperan untuk memberikan pengawasan lebih intensif, memilih teman sebaya lebih selektif dan mendidik agar lebih taat beribadah, memberikan waktu luang lebih banyak untuk berkomunikasi dengan anak, tidak sibuk dengan pekerjaaannya sehingga anak tidak merasa kesepian (Wildan, 2012).

Berdasarkan hal tersebut, bahwa lingkungan keluarga sangat mempengaruhi bagi perkembangan kepribadian anak, dalam hal ini orang tua harus berusaha untuk menciptakan lingkungan keluarga yang sesuai yakni suasana serasi, seimbang dan selaras, orang tua harus bersikap demokrasi baik dalam memberikan aturan maupun larangan dan berupaya melatih anak menjadi percaya diri dan mandiri. Selain hal tersebut, orang tua juga perlu menanamkan nilai-nilai agama juga agar remaja memiliki pedoman hidup yang benar, sebagaimana yang kita ketahui dalam agama Islam, orang tua memiliki kewajiban untuk memelihara dirinya dan keluarganya dari siksa api neraka dengan beragama yang benar.

Berdasarkan hasil penelitian terdapat hubungan antara pengaruh teman sebaya dengan perilaku seksual pra nikah. Hasil penelitian menyatakan mayoritas reponden memiliki pengaruh yang tinggi dari teman sebaya dengan perilaku seksual pra nikah berisiko tinggi sebanyak 88 responden $(60,3 \%)$. Hal tersebut sesuai dengan hasil penelitian Joko Sapto Pramono et al. (2010) dari 102 responden dengan pengaruh teman sebaya negatif sebanyak 62 responden $(48,4 \%)$ pernah melakukan perilaku seksual.

Teman sebaya merupakan orang yang dianggap penting oleh remaja masa pertengahan dan akhir, sehingga peran orang tua yang berpengaruh terhadap konsep diri anak semakin sedikit bahkan bisa tergantikan perannya karena di dominasi oleh peran teman sebayanya. Anak semakin mengidentifikasikan diri dengan anak-anak seusianya dan mengikuti bentuk-bentuk tingkah laku kelompok teman sebayanya. Remaja akan merasa bahagia jika diterima kawan sebayanya dan sebaliknya akan merasa stress jika dikeluarkan oleh kawan sebayanya. Selain itu remaja juga sangat mempercayai kawan sebayanya dalam 
menceritakan sesuatu hal dibanding dengan keluarga. Hal tersebut memicu terjadinya perilaku seksual dini yang dilakukan oleh remaja terkait pergaulannya dengan teman sebaya yang negatif (Agustiani, 2009).

Hasil penelitian Darmayanti et al. (2011) menunjukkan bahwa peran teman sebaya yang pasif dalam memberikan informasi mengenai kesehatan seksual, memiliki peluang berperilaku seksual pranikah berat 2,6 kali dibandingkan dengan peran teman sebaya yang aktif dalam memberikan informasi mengenai kesehatan seksual. Darmayanti mengatakan perilaku remaja dapat dipengaruhi oleh pergaulan teman sebayanya. Pengaruh tersebut seperti pengaruh positif dan negatif. Ketika remaja bergaul dengan teman-teman sebayanya yang memberikan manfaat seperti belajar kelompok maka teman sebaya memberikan pengaruh yang positif, sebaliknya teman sebaya yang memberikan pengaruh negatif seperti yang mengajak remaja melanggar norma-norma sosial.

Yusuf (2005) mengatakan bahwa dalam kepribadian remaja memiliki konformitas (motif untuk menjadi sama, sesuai, seragam) dengan teman sebayanya dalam hal melakukan hobi ataupun cara berpakaian, sehingga erat kaitannya remaja cenderung meniru atau mengikuti teman sebayanya yang sudah pernah melakukan perilaku seksual pranikah. Hal tersebut sesuai dengan hasil penelitian yang menyebutkan bahwa mayoritas responden menyatakan sahabat/ teman-teman menganggap wajar jika seusia remaja berpacaran sehingga remaja rentan ingin memiliki pacar jika sahabatnya sudah memiliki pacar dan menceritakan perilaku yang biasa dilakukan oleh remaja yang berpacaran. Artinya kelompok teman sebaya yang memiliki pengaruh negatif lebih mudah mempengaruhi remaja dibanding yang memiliki pengaruh positif. Penelitian Suparmi and Isfandari (2016) menunjukkan hasil yang sama yaitu ada hubungan antara peran teman sebaya terhadap perilaku seksual pra nikah remaja. Suparmi dan Isfandari mengatakan remaja yang memiliki teman pernah melakukan hubungan seks pra nikah lebih besar kemungkinan untuk ikut melakukan perilaku seks berisiko seperti konsumsi alkohol, obatobatan terlarang maupun tertular HIV/ AIDS.

Perilaku seks berisiko merupakan suatu aktivitas seksual, yang berkaitan dengan hubungan seks vaginal dan anal yang dilakukan dengan pasangan seksnya sehingga menjadi rentan tertular penyakit 
menular seksual seperti HIV/AIDS. Remaja yang pernah melakukan perilaku seks berisiko rendah rentan akan melakukan ke tahap selanjutnya yakni perilaku seks berisiko tinggi yang kemudian akan rentan tertular penyakit menular seksual. Meskipun dalam penelitian ini tidak ada responden yang pernah melakukan oral seks dan senggama, responden dikhawatirkan akan melakukan hal tersebut seiring kebiasaan yang sering dilakukan dan faktor-faktor lain yang mempengaruhinya (Rahardjo, 2013). Salah satu peranan penting orang tua bagi kehidupan remaja yakni memberikan kebebasan kepada remaja untuk berkumpul bersama kawa-kawan sebaya dan mengawasi kehidupan mereka. Orang tua dapat memberikan contoh/model atau mendidik remajanya dalam hal menjalin hubungan dengan kawan-kawan sebayanya.

Berdasarkan studi literatur menyatakan ada strategi-strategi tententu yang direkomendasikan orang tua dalam membantu remaja mengembangkan relasi yang lebih positif dengan kawan-kawan sebayanya. Diantaranya diskusi tentang cara remaja mereduksi pertikaian/ perselisihan dan sifat pemalu. Orang tua juga mendukung remajanya agar lebih menghargai perbedaan dan mampu menolak desakan dari kawan-kawan sebaya (Santrock, 2007).Menurut Santrock (2003) sebagian besar remaja membicarakan mengenai hal-hal seksual lebih bebas dengan teman sebaya dibandingkan dengan orang tuanya. Pada umumnya informasi yang didapat dari teman sebaya lebih mudah dan terbuka tetapi lebih banyak mengandung unsurunsur pengalaman seksual yang mencerminkan adanya sex appeal.

Keterbukaan dalam memberikan informasi yang membuat adanya keterbatasan informasi dari orang tua atau keluarga. Muatan informasi yang tersebut dapat mengakibatkan remaja pada perilaku seksual yang kurang sehat dilihat dari sisi moral, mental, ataupun medis. Tidak heran banyak informasi yang salah sering mereka terima (Joko Sapto Pramono et al., 2010).

Berdasarkan hal tersebut, peneliti berpendapat bahwa remaja belajar bersosialisasi melalui kawan sebaya. Remaja belajar berbagai hal yang diterapkan dalam kehidupan sehari-hari. Oleh karena itu, kawan sebaya mempunyai pengaruh besar terhadap perkembangan pribadi remaja. Tidak menutup kemungkinan, kawan sebaya memberikan pengaruh negatif terhadap perkembangan diri individu. Hal ini dapat dipengaruhi proses sosialisasi melalui kawan 
sebaya berjalan tanpa pengawasan dari orang tua atau guru.

Pengaruh yang diberikan teman sebaya dapat berupa nasehat-naehat yang diberikan teman kepada remaja, namun terkadang nasehat yang diberikan sering kali tidak mempertimbangkan baik dan buruknya, misal saat teman memberikan masukan bahwa berpacaran itu suatu hal yang wajar atau umum yang dilakukan remaja zaman sekarang bahkan tidak sedikit orang berpendapat jika tidak memiliki pacar disebut ketinggalan zaman, sehingga banyak sebagian dari remaja merasa malu untuk mengakui bahwa mereka tidak memiliki pacar yang pada akhirnya remaja melakukan berbagai cara untuk mendapatkan pacar. Selain itu teman sebaya atau sahabat seringkali merasa sungkan untuk mengatakan yang sebenarnya atas perbuatan yang keliru yang dilakukan oleh sahabatnya sehingga teman sebaya atau sahabat selalu mendukung apa yang dilakukan sahabatnya walaupun yang dilakukan sahabatnya itu menyimpang baik dari segi norma sosial dan juga norma agama.

Berdasarkan hasil penelitian terdapat hubungan antara sikap dengan perilaku seksual pra nikah. Hasil penelitian menyatakan mayoritas responden memiliki sikap yang positif terhadap kesehatan reproduksi dengan perilaku seksual pra nikah berisiko rendah sebanyak 104 responden $(61,2 \%)$.Hal tersebut sejalan dengan hasil penelitian Nursal (2008) yaitu remaja dengan sikap relatif negatif memiliki peluang 9,94 kali berperilaku seksual berisiko berat dibanding sikap relatif positif $(95 \% \mathrm{CI}=4,14-23,6)$.

Sikap adalah suatu bentuk evaluasi atau reaksi perasaan mendukung (favorable) atau tidak mendukung (unfavorable) terhadap suatu objek. Sikap mempunyai arah, yaitu setuju atau tidak setuju terhadap suatu objek. Remaja yang semakin setuju atau mendukung terhadap kesehatan reproduksi artinya remaja tersebut memiliki sikap yang arahnya positif, dan sebaliknya (Azwar, 2011).Penelitian Sri Putri Murtini Puspita et al. (2012) pada 95 responden menunjukkan hasil yang sama yaitu responden yang memiliki perilaku seks ringan dengan sikap positif sebesar 78 orang $(70,9 \%)$. Asna (2011) mengatakan sikap adalah respon tertutup yang tidak dapat dilihat langsung dan merupakan predisposisi tingkah laku. Dalam hal ini dapat diartikan jika remaja mempunyai sikap positif yang tinggi maka remaja tersebut mempunyai sikap positif terhadap berbagai jenis perilaku seksual. 
Sikap merupakan respon evaluatif. Respon hanya akan muncul jika dihadapkan pada suatu reaksi individual. Respon evaluatif berarti reaksi yang dinyatakan sebagai sikap yang didasari oleh proses evaluasi dalam diri individu yang memberihasil akhir terhadap stimulus dalam bentuk nilai baik buruk, positif negatif, menyenangkan tidak menyenangkan, yang kemudian mengkristal sebagai potensi reaksi terhadap obyek sikap. Penelitian lain yang dilakukan oleh (Syamsulhuda B. Musthofa and Winarti, 2010) responden yang mempunyai sikap lebih permisif mempunyai besar risiko untuk melakukan sebesar 3,473 kali dibandingkan responden yang mempunyai sikap kurang permisif terhadap perilaku seks pranikah.

Menurut Azwar (2011) sikap memiliki konsistensi, artinya kesesuaian antara pernyataan sikap yang dikemukakan dengan responnya terhadap suatu objek sikap yang dimaksud. Konsistensi sikap diperlihatkan oleh kesesuaian sikap antar waktu. Agar dapat konsisten sikap harus bertahan dalam diri individu dalam waktu yang relatif panjang. Artinya responden yang sudah memiliki sikap positif harus memiliki konsistensi terhadap apa yang ia sikapi dengan mempertahankan sikap positifnya dalam waktu yang lama agar sikap tidak dapat berubah-ubah.Selain hal di atas, Azwar (2011) mengatakan sikap dapat dipengaruhi oleh beberapa faktor yaitu pengalaman pribadi, pengaruh orang lain yang di anggap penting seperti orang tua yang menganggap khitanan perlu dilakukan untuk menjaga kesehatan reproduksi, pengaruh kebudayaan bahwa hamil di luar nikah tidak boleh aborsi, media massa, lembaga pendidikan dan lembaga agama yang melarang pacaran berduaan, berpegangan tangan dan meremas bagian sensitif lawan jenis, faktor emosional. Sikap dapat dipengaruhi oleh beberapa faktor diantaranya pengalaman pribadi, pengaruh dari orang lain (teman sebaya), dan pengaruh emosional sebagai pengalihan pertahanan ego (Wahareni, 2006).

Berdasarkan hal tersebut, peneliti berpendapat bahwa kecenderungan seseorang untuk bertindak atau bertingkah laku berbeda dalam situasi yang sama. Hal itu disebabkan oleh perbedaan sikap. Kecenderungan seseorang untuk bertindak dapat bersifat positif dan negatif. Apabila seseorang memiliki kecenderungan yang positif terhadap suatu objek maka ia akan bersikap membantu, memperhatikan, berbuat sesuatu yang baik, menerima sesuatu dengan baik. Sebaliknya, bila seseorang memiliki sikap negatif terhadap suatu objek, 
ia akan mencela, menolak, dan tidak menyukai objek tersebut.

\section{KESIMPULAN}

Kesimpulan dari hasil penelitian adalah sebagai berikut :

1. Sebagian besar siswa-siswi SMA Negeri 1 Jamblang Kabupaten Cirebon tahun 2017 memiliki peran orang tua yang baik, mendapatkan pengaruh yang tinggi dari teman sebaya, memiliki sikap positif terhadap kesehatan reproduksi dan memiliki perilaku seksual pra nikah berisiko rendah.

2. Terdapat hubungan antara peran orang tua, pengaruh teman sebaya dan sikap dengan perilaku seksual pra nikah pada siswa-siswi SMA Negeri 1 Jamblang Kabupaten Cirebon tahun 2017.

\section{REFERENSI}

Agung. (2016). Keperjakaan dan Keperawanan Generasi Milenial. Available: https://goo.gl/gn4wIc [Accessed 0501-2017].

Agustiani, H. (2009). Psikologi Perkembangan Pendekatan Ekologi Kaitannya dengan Konsep Diri dan Penyesuaian Diri pada Remaja), Bandung: Refika Aditama.

Asna, K. (2011).Hubungan Antara Pengetahuan Dan Sikeap Terbadap Kesehatan Reproduksi Dengan Perilaku Seksual Pra Nikah Pada Siswa Di Sma Negeri 14 Kota Semarang Tabun Ajaran 2010/2011. Semarang: Universitas Negeri Semarang.
Azwar, S. (2011) Sikap Manusia Teori dan Pengukurannya, Yogyakarta: Pustaka Pelajar.

Christina, T. (2014). Konsep Teman Sebaya. Available: https://goo.gl/JVAIOy [Accessed 04-01-2017].

Darmasih, R. (2009).Faktor Yang Mempengarubi Perilaku Seks Pranikah Pada Remaja SMA Di Surakarta. Surakarta: Universitas Muhammadiyah Surakarta.

Darmayanti, Yuniar Lestari \& Ramadani, M. (2011). Peran Teman Sebaya Terhadap Perilaku Seksual Pranikah Siswa SLTA Kota Bukittinggi. Kesehatan Masyarakat, $6(1)$.

Fridya Mayasari \& Hadjam, M. N. R. (2000) Perilaku Seksual Remaja Dalam Berpacaran Ditinjau Dari Harga Diri Berdasarkan Jenis Kelamin. Psikologi, (2) $120-127$.

Joko Sapto Pramono, Artike Dewi \& Auliatunida, Z. (2010) Pengaruh Teman Sebaya Terhadap Perilaku Seksual Pada Remaja Di Sma Negeri 8 Samarinda Tahun 2010. Jurnal Husada Mahakam, Vol. III No. 2 45-94.

Nirmajanti, D. (2015).Hubungan Peran Orang Tua Dalam Memberikan Pendidikan Seks Pranikah dengan Perilaku Seks Pranikah pada Siswa Kelas X di SMKN 2 Sewon Bantul Yogyakarta. Yogyakarta: Sekolah Tinggi Ilmu Kesehatan 'Aisyiyah.

Notoatmodjo, S. (2003).Pendidikan dan Perilaku Kesehatan, Jakarta: Rineka Cipta.

Nursal, D. G. A. (2008).Faktor-Faktor Yang Berhubungan Dengan Perilaku Seksual Murid Smu Negeri di Kota Padang 
Tahun 2007. Kesehatan Masyarakat, II (2).

Nuzulia Rahayu, Yusniawarti Yusad \& Lubis,

R. M. (2013).Pengaruh Kegiatan Penyuluban Dalampelayanan Kesehatan Peduli Remaja (PKPR) Terhadap Pengetabuan Dan Sikap Remaja Tentang Seks Pranikah Di Sman 1 Lubuk Dalam Kabupaten Siak Sri Indrapura Tabun 2013. Medan: Universitas Sumatera Utara.

Pratiwi, L. (2016).Pengaruh Lingkungan Pergaulan Sekolah dan Dukungan Keluarga Terbadap Sikap Kesehatan Reproduksi Siswa - Siswi Di Kelas X SMK Budi Tresna Mubammadiyah Kabupaten Cirebon. Bandung: Universitas Padjadjaran.

Purba, B. (2014). Perilaku Seksual. Available: https://goo.gl/gPOkaN [Accessed 0601-2017].

Pusat Data dan Informasi Kementerian Kesehatan Republik Indonesia. (2012) Info Datin: Situasi Kesehatan Reproduksi Remaja. Jakarta Selatan: Pusat Data dan Informasi Kementrian Kesehatan RI.

Qomarasari, D. (2015) Hubungan Antara Peran Keluarga, Sekolah, Teman Sebaya, Pendapatan Keluarga, Media Informasi Dan Norma Agama Dengan Perilaku Seksual Remaja Sma Di Surakarta. Semarang: Universitas Negeri Semarang.

Rahardjo, W. (2013). Model Perilaku Seks Berisiko pada Pria. Available: https://goo.gl/9FwVt4 [Accessed 2903-2017].

Santrock, J. W. (2007) Remaja, Jakarta: Erlangga.

Sarwono, S. W. (2007) Psikologi Remaja, Jakarta: Raja Grafindo Persada.
Soetjiningsih (2004) Tumbub Kembang Remaja dan Permasalahannya, Jakarta: Rineka Cipta.

Sri Putri Murtini Puspita, Muhammad Iksan \& Rahma. (2012).Pengetahuan, Sikap, Peran Orang Tua Perilaku Seks Remaja Siswa Smk Negeri 4 Jeneponto. Makassar: UNHAS.

Sugiyono (2013).Metode Penelitian Kuantitatif, Kualitatif, dan R\&D, Bandung: Alfabeta.

Sulistianingsih, A. (2010).Hubungan Lingkungan Pergaulan Dan Tingkat Pengetabuan Tentang Kesehatan Reproduksi Dengan Sikap Seks Bebas Pada Remaja. Surakarta: Universitas Sebelas Maret.

Sulistyaningsih (2012) Metodologi Penelitian Kebidanan: Kuantitatif-Kualitatif, Yogyakarta: Graha Ilmu.

Suparmi \& Isfandari, S. (2016). Peran Teman Sebaya terhadap Perilaku Seksual Pranikah pada Remaja Laki-Laki dan Perempuan di Indonesia. Buletin Penelitian Kesehatan, 44 (2) 139-146.

Susila \& Suyanto (2014).Metodologi Penelitian Cross Sectional, Klaten: Bossscript.

Syamsulhuda B. Musthofa \& Winarti, P. (2010).Faktor Yang Mempengaruhi Perilaku Seks Pranikah Mahasiswa Di Pekalongan Tahun 2009-2010. Kesehatan Reproduksi, 1 (1) 33-41.

Wahareni, P. A. (2006).Sikap Remaja Terhadap Perilaku Seks Bebas Ditinjan Dari Tingkat Penalaran Moral Pada Siswa Kelas Dua Sma Kesatrian 1 Semarang Tabun Ajaran 2005/2006 (Teori Perkembangan Moral Köhlberg). Semarang: Universitas Negeri Semarang. 
Jurnal Care Vol .6, No.2,Tahun 2018

Wildan. (2012).Pengarub Pola Asub Orangtua Dan Teman Sebaya Terbadap Konsep Diri Remaja Tentang Perilaku Seksual Di Sma Negeri 2 Dan Man 2 Medan Tabun 2012. Medan: Universitas Sumatera Utara.
Yusuf, S. (2005) Psikologi Perkembangan Anak dan Remaja, Bandung: Remaja Rosdakarya. 